Article

\title{
Susceptibility of Asialoglycoprotein Receptor-Deficient Mice to LPS/Galactosamine Liver Injury and Protection by Betaine Administration
}

\author{
Karuna Rasineni ${ }^{1,2}$, Serene M. L. Lee ${ }^{2,+}{ }^{\text {, Benita L. McVicker }}{ }^{1,2}$, Natalia A. Osna ${ }^{1,2}$ (D) Carol A. Casey ${ }^{1,2,3}$ (D) \\ and Kusum K. Kharbanda 1,2,3,*(D)
}

1 Research Service, Veterans' Affairs Nebraska-Western Iowa Health Care System, Omaha, NE 68105, USA; karuna.rasineni@unmc.edu (K.R.); bmcvicker@unmc.edu (B.L.M.); nosna@unmc.edu (N.A.O.); ccasey@unmc.edu (C.A.C.)

2 Department of Internal Medicine, University of Nebraska Medical Center, Omaha, NE 68198, USA; Serene.Lee@med.uni-muenchen.de

3 Department of Biochemistry and Molecular Biology, University of Nebraska Medical Center, Omaha, NE 68198, USA

* Correspondence: kkharbanda@unmc.edu; Tel.: +1-402-995-3752; Fax: +1-402-995-4600

+ Current Address: Department of General, Visceral and Transplant Surgery, Ludwig-Maximilians-University Munich, 5H 02 Room 428, Marchioninistr. 15, 81377 Munich, Germany.

check for updates

Citation: Rasineni, K.; Lee, S.M.L.; McVicker, B.L.; Osna, N.A.; Casey,

C.A.; Kharbanda, K.K. Susceptibility of Asialoglycoprotein Receptor-Deficient Mice to LPS/Galactosamine Liver Injury and Protection by Betaine Administration. Biology 2021, 10, 19. https://doi.org/10.3390/

biology10010019

Received: 3 December 2020 Accepted: 27 December 2020 Published: 31 December 2020

Publisher's Note: MDPI stays neutral with regard to jurisdictional clai$\mathrm{ms}$ in published maps and institutional affiliations.

Copyright: (C) 2020 by the authors. Licensee MDPI, Basel, Switzerland. This article is an open access article distributed under the terms and conditions of the Creative Commons Attribution (CC BY) license (https:// creativecommons.org/licenses/by/ $4.0 /)$.
Simple Summary: Previous studies from our laboratory have shown that chronic ethanol exposureinduced increase in apoptotic hepatocellular death is closely related to the ethanol-induced impairment in asialoglycoprotein receptor, a major component of liver sugar recognition system. The aim of this study was to examine whether the absence of this receptor confers increased susceptibility to fulminant liver failure induced by lipopolysaccharide/galactosamine. We further investigated whether treatment with betaine, a naturally occurring tertiary amine, prior to lipopolysaccharide/galactosamine injection is protective. Lipopolysaccharide/galactosamine injection caused a more pronounced liver damage in asialoglycoprotein receptor-deficient compared with the wild-type control mice. In addition, prior administration of betaine was found to significantly attenuate the lipopolysaccharide/galactosamine-induced increases in several liver injury parameters. Our work underscores the importance of normal functioning of asialoglycoprotein receptor in preventing severe liver damage and signifies a therapeutic role of betaine in prevention of liver injuries from toxin-induced fulminant liver failure.

Abstract: Background: Work from our laboratory has shown that the ethanol-induced increase in apoptotic hepatocellular death is closely related to the impairment in the ability of the asialoglycoprotein receptor (ASGP-R) to remove neighboring apoptotic cells. In this study, we assessed the role of ASGP-R in fulminant liver failure and investigated whether prior treatment with betaine (a naturally occurring tertiary amine) is protective. Methods: Lipopolysaccharide (LPS; $50 \mu \mathrm{g} / \mathrm{kg} \mathrm{BW)} \mathrm{and} \mathrm{galactosamine}$ (GalN; $350 \mathrm{mg} / \mathrm{kg} \mathrm{BW)} \mathrm{were} \mathrm{injected} \mathrm{together} \mathrm{to} \mathrm{wild-type} \mathrm{and} \mathrm{ASGP-R-deficient} \mathrm{mice} \mathrm{that} \mathrm{were}$ treated for two weeks prior with or without $2 \%$ betaine in drinking water. The mice were sacrificed $1.5,3$, or 4.5 h post-injection, and tissue samples were collected. Results: LPS/GalN injection generate distinct molecular processes, which includes increased production of tumor necrosis factor- $\alpha$ (TNF- $\alpha$ ) and interleukin-6 (IL-6), thus causing apoptosis as evident by increased caspase-3 activity. ASGP-R deficient animals showed increased liver caspase activities, serum TNF- $\alpha$ and IL-6 levels, as well as more pronounced liver damage compared with the wild-type control animals after intraperitoneal injection of LPS/GalN. In addition, prior administration of betaine was found to significantly attenuate the LPS/GalN-induced increases in liver injury parameters. Conclusion: Our work underscores the importance of normal functioning of ASGP-R in preventing severe liver damage and signifies a therapeutic role of betaine in prevention of liver injuries from toxin-induced fulminant liver failure.

Keywords: lipopolysaccharide; galactosamine; apoptosis; betaine; fulminant liver failure 


\section{Introduction}

Fulminant liver failure results from massive hepatocyte death and severely impairs liver functions. This clinical syndrome has a high mortality rate despite several options available such as liver support systems and liver transplantation [1-4].

A well-established and widely used experimental model of fulminant hepatic failure is the combined administration of lipopolysaccharide (LPS) and galactosamine (GalN) [5-8]. Both inflammation and apoptosis are consistently observed in a number of inbred and outbred strains tested with this model $[9,10]$. Further, distinct molecular processes have been identified in LPS/GalN liver injury. It has been shown that the metabolism of GalN leads to hepatotoxicity through inhibition of mRNA and protein synthesis; this occurs due to the concurrent accumulation of UDP-GalN derivatives and a depletion of hepatic UTP [11]. This GalN "priming" leads to the potentiation of the toxic effects of LPS to produce typical hepatic cell injury followed by fulminant liver failure within $4-6 \mathrm{~h}$ of LPS/GalN administration [12,13]. In particular, TNF- $\alpha$ production by the LPS-activated Kupffer cells $(\mathrm{KC})$ that primarily causes apoptosis of GalN-"primed" hepatocytes at an early stage in LPS/GalN-induced liver injury $[14,15]$. TNF- $\alpha$ is also responsible for the upregulation of the adhesion molecules, CXC chemokine formation, the activation of polymorphonuclear neutrophils (PMNs), and their sinusoidal accumulation [16]. GalN/TNF- $\alpha$ also induces gap formation in endothelial cells, which allows PMNs to recognize apoptotic hepatocytes. This is the trigger for PMN extravasation and attack on injured cells. These events aggravate and accelerate parenchymal cell injury leading to necrosis of hepatocytes at a later stage $[17,18]$. In addition, the failure of the sinusoidal endothelial cells (SEC) barrier causes hemorrhage in the liver resulting in hypovolemic shock, which eventually kills the animal [19].

It has been shown that even if CXC chemokine formation and the PMN attack is prevented, the apoptosis continues to increase and eventually similar extent of injury is observed $[16,20]$, signifying apoptosis as being germane to LPS/GalN-induced fulminant liver failure.

Our previous research has shown that the function of the asialoglycoprotein receptor (ASGP-R), a major component of liver sugar recognition system, is impaired following chronic exposure to ethanol. Further work in our laboratory has shown that the increase in hepatocellular apoptosis observed after ethanol consumption is closely related to the impaired ability of the ASGP-R to remove apoptotic cells; one of the most important physiological ligands of this receptor [21,22]. The generation of the ASGP-R deficient mouse strain has provided us with a tool to understand the physiological role of ASGP-R. Since hepatocellular apoptosis has been shown to be a major player in LPS/GalN injury, one of the aims of this study is to assess if the loss of ASGP-R makes these mice more susceptible than wild-type controls to LPS/GalN-induced fulminant liver failure.

Only $14 \%$ of patients diagnosed with fulminant liver failure recover with medical therapy. While orthotopic liver transplantation has improved the chances of survival of patients with fulminant liver failure, there is a high risk associated with immunosuppressive agents used in transplant patients [1,2]. Therefore, there is a need to identify anti-apoptotic agents that could be effectively used to treat fulminant liver failure. Several studies conducted in our and other laboratories have shown that betaine can mitigate liver diseases of diverse etiology such as alcohol [23-34], carbon tetrachloride exposure [35-38], high-caloric intake, and metabolic syndrome related [39-45]. There are also numerous publications demonstrating betaine's protective role in apoptosis [24,46-48]. Thus, we also wanted to examine whether prior administration of betaine could protect these ASGP-R-deficient mice from developing severe liver injury following LPS/GalN injection.

\section{Materials and Methods}

\subsection{Animals}

Wild-type C57B16/129SV F2 cross mice (WT) and ASGP-R-deficient (RD) mice of the same strain were obtained from Jackson Laboratories (Bar Harbor, ME, USA). As described 
in our earlier publications, RD mouse was developed by abolishing MHL-2 gene that encodes the minor subunit of ASGP receptor [49,50]. RD mice do not show any phenotypic abnormalities. Female mice (20-22 g) were fed with $2 \%$ betaine in drinking water or water alone for 2 weeks and then randomized to be injected intraperitoneally with either saline or a solution of LPS (E.coli 026:B6, Sigma\# L2654; $50 \mu \mathrm{g} / \mathrm{kg} \mathrm{BW)} \mathrm{and} \mathrm{GalN} \mathrm{(350} \mathrm{mg/Kg} \mathrm{BW).}$ The mice were sacrificed $1.5,3$, or $4.5 \mathrm{~h}$ post-injection $[5,6]$. At necroscopy, the liver was removed, and portions were either immediately processed for histological examination or snap frozen in liquid nitrogen and stored at $-70^{\circ} \mathrm{C}$ for caspase enzyme analysis. Blood samples were collected via the axillary artery and the prepared sera were stored at $-70^{\circ} \mathrm{C}$ until analyzed for AST/ALT activities and cytokine levels. The care and use of these mice and the procedures performed on them were approved by the Institutional Animal Care and Use Committee at the Omaha Veterans Affairs Medical Center.

\subsection{Serum Transaminase}

Serum alanine aminotransferase (ALT)/aspartate aminotransferase (AST) levels were determined using the VITROS 5.1 FS Chemistry System (Ortho Clinical Diagnostics, Raritan, NJ, USA).

\subsection{Serum Cytokine Levels}

Tumor necrosis factor- $\alpha$ (TNF- $\alpha$ ) and interleukin-6 (IL-6) levels were measured using the BD OptEIA Mouse TNF- $\alpha$ and IL-6 ELISA kit purchased from BD Biosciences, San Diego, CA, USA.

\subsection{Histopatholog}

Paraffin-embedded liver tissue sections were processed for hematoxylin/eosin staining for histological evaluation. The severity of liver injury was assessed by evaluating portal inflammation, hepatocellular necrosis, inflammatory cell infiltration, and loss of cell architecture.

\subsection{TUNEL Assay}

The formalin-fixed liver tissue was also processed and stained with terminal deoxynucleotidyl transferase-mediated dUTP nick-end labeling (TUNEL). The number of apoptotic hepatocytes was quantified based on positive TUNEL staining and morphological criteria. Apoptotic hepatocytes were counted individually for five independent sections and expressed as the average number of TUNEL-positive cells per microscopic field.

\subsection{Caspase-3 Activation Assay}

Portions of frozen livers were processed and then assayed for specific caspase activities following manufacturers' instructions using commercially available caspase-3 fluorogenic substrate, Ac-DEVD-AMC (BD Biosciences, San Diego, CA, USA). Caspase activity was evaluated by measuring the release of AMC (7-Amino-4-methylcoumarin) obtained by the cleavage of the defined synthetic peptide sequence by caspase-3, using a Perkin Elmer Luminescence Spectrophotometer LS 50B. Free AMC obtained from Sigma-Aldrich (St Louis, MO, USA) was used as the standard. Protein was determined using the BCA Protein Assay kit from Pierce. The caspase- 3 activity was expressed as pmoles of AMC produced per mg liver protein.

\subsection{Statistical Analyses}

The results were presented as mean \pm SEM. Data were analyzed by one-way ANOVA, followed by Tukey test. A $p$ value $<0.05$ was regarded as statistically significant. 


\section{Results}

\subsection{Histological Changes}

Histological analysis of WT mice injected with saline or sub-lethal dose of LPS/GalN revealed a normal liver lobular architecture. (Figure 1). The same features were also seen in RD mice injected with saline. However, the mice injected with LPS/GalN showed areas of portal inflammation and apoptotic hepatocytes, which was randomly distributed throughout the parenchyma. These mice also had a moderate increase in inflammatory cell infiltration and hemorrhage. These pathological changes were ameliorated by betaine pretreatment.
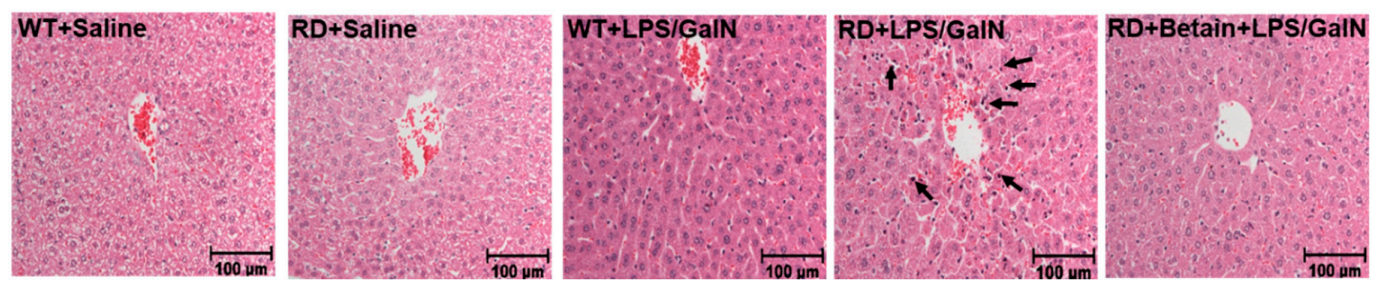

Figure 1. Histology of livers from wild-type (WT) and asialoglycoprotein (ASGP) receptor-deficient (RD) mice. Paraffin embedded sections were prepared and stained with hematoxylin and eosin stain (H \& E). Photographs (200× magnification) show representative liver sections of saline or lipopolysaccharide (LPS)/galactosamine (GalN)-injected WT and RD mice. After $4.5 \mathrm{~h}$ of LPS/GalN injection, RD mice showed increased apoptotic hepatocytes (arrows) and areas of hemorrhage, which were reduced with betaine pretreatment.

\subsection{Serum ALT and AST Levels}

ALT and AST levels, serum markers of hepatocyte injury, were within normal range in the saline-treated WT and RD mice at all time-points examined. Both WT and RD animals injected with LPS/GalN showed increases in serum liver injury markers only at $4.5 \mathrm{~h}$ post-injection. Whereas the WT exhibited a modest ( $<$ than 2-fold) increase in AST levels only, RD mice showed an over4-fold increase in both AST and ALT levels compared to saline-injected miceBetaine pretreatment significantly attenuated the AST and ALT levels in LPS/GalN-injected RD mice (Figure 2).

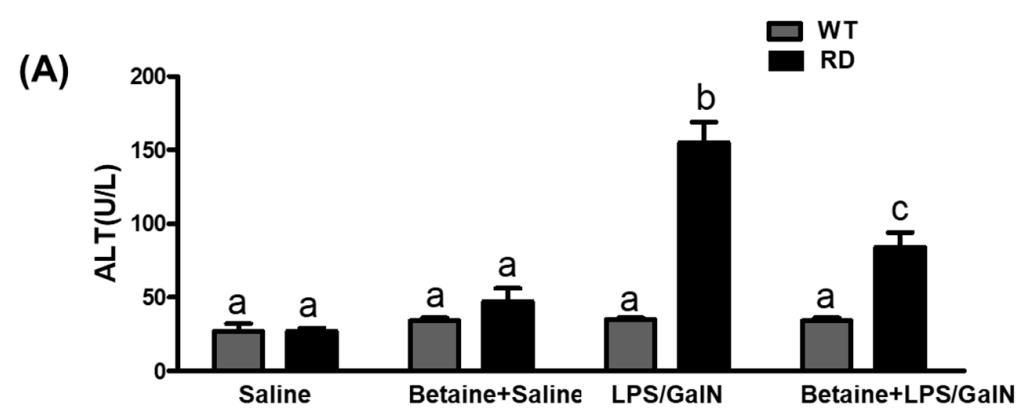

(B)

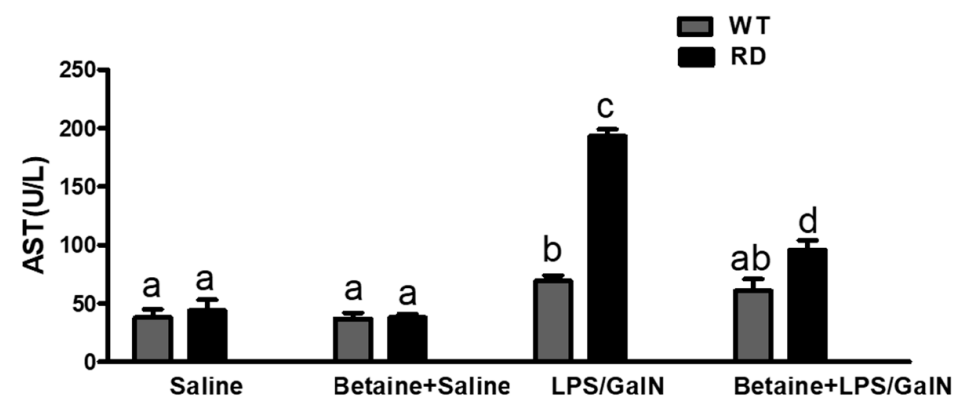

Figure 2. Effect of LPS/GalN and betaine on (A) serum alanine aminotransferase (ALT) and (B) aspartate aminotransferase (AST) levels. Values are means \pm SEM $(n=8)$. Values not sharing a common letter are statistically different, $p<0.05$. 


\subsection{Cytokine Levels}

We observed TNF- $\alpha$ serum levels peaked at $1.5 \mathrm{~h}$ post-LPS/GalN injection and RD mice showed significantly higher TNF- $\alpha$ compared to the WT mice under the same conditions. These levels declined at $3 \mathrm{~h}$ in both $\mathrm{WT}$ and RD mice and reached to baseline at $4.5 \mathrm{~h}$ post LPS/GalN injection in WT animals but not in RD animals. Betaine treatment did not attenuate the LPS/GalN induced increase in TNF- $\alpha$ levels in either the RD or WT mice (Figure 3).

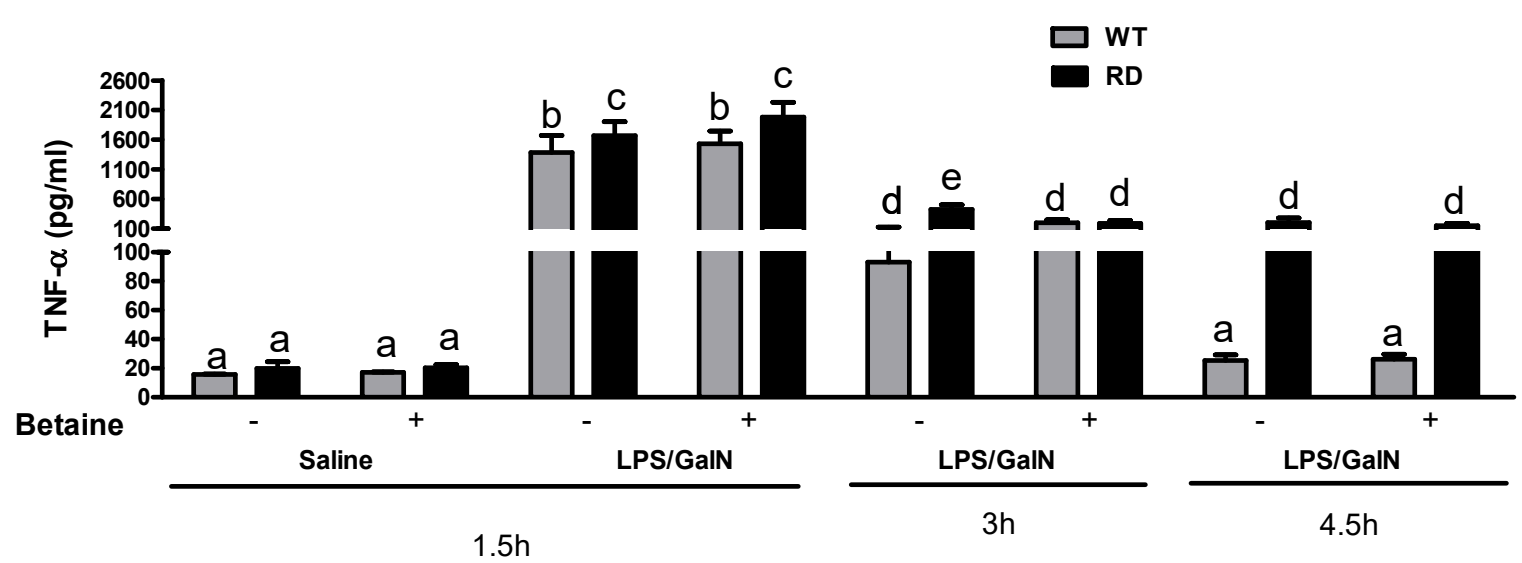

Figure 3. Effect of LPS/GalN and betaine on serum TNF- $\alpha$ levels. ELISA analysis of TNF- $\alpha$ concentration changes in serum at $1.5,3$, and $4.5 \mathrm{~h}$ after saline or LPS/GalN injection. Values are means $\pm \mathrm{SEM}(\mathrm{n}=8)$. Values not sharing a common letter are statistically different, $p<0.05$.

Contrary to the serum TNF- $\alpha$ profile, the increases in serum IL-6 levels were sustained for a longer period after LPS/GalN injection in both the WT and RD mice. However, the levels of IL-6 were higher in RD mice at 3 and $4.5 \mathrm{~h}$ after LPS/GalN injection relative to the levels observed in WT mice under the same conditions. Betaine partially attenuated the IL-6 release in RD mice at these later time points (Figure 4).

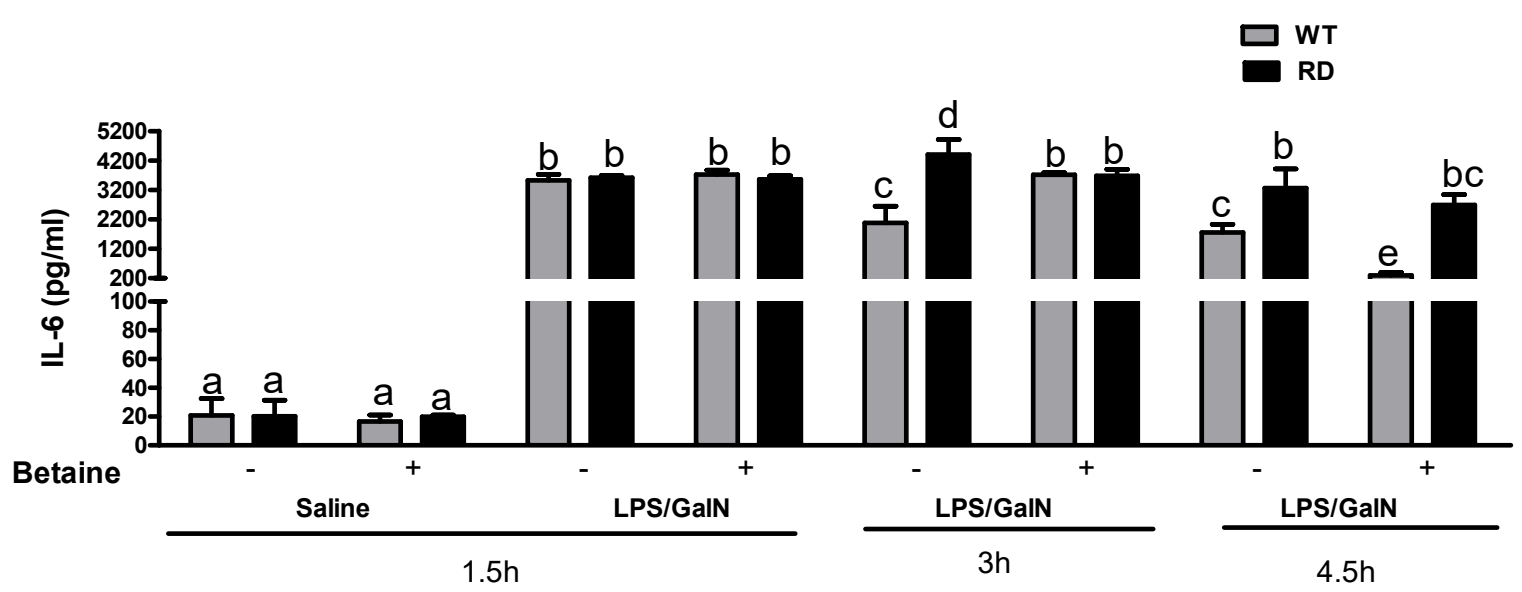

Figure 4. Effect of LPS/GalN and betaine on serum IL-6 levels in WT and RD mice. ELISA analysis of IL-6 concentration in serum at 1.5, 3, and $4.5 \mathrm{~h}$ after saline or LPS/GalN administration in WT and RD mice with or without betaine pretreatment were measured. Values are means $\pm \operatorname{SEM}(n=8)$. Values not sharing a common letter are statistically different, $p<0.05$.

\subsection{Hepatocyte Apoptosis}

Caspase- 3 activity was at baseline at all times in the liver of saline-injected WT and RD mice. A significant increase in caspase 3 activity was noted in RD mice only at $4.5 \mathrm{~h}$ after LPS/GalN injection. In contrast, only a modest increase in caspase-3 activity in WT mice 
injected with LPS/GalN at $4.5 \mathrm{~h}$ post-injection. This increase was attenuated in betaine pretreated RD mice (Figure 5).

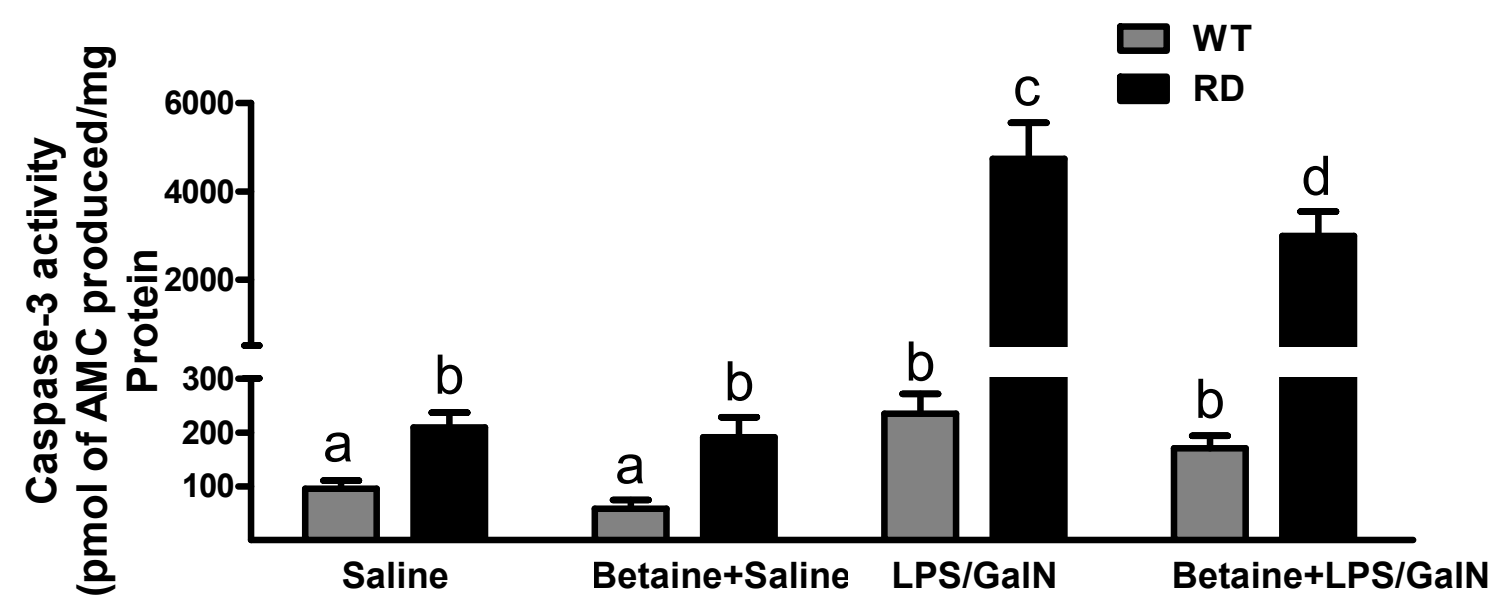

Figure 5. Caspase- 3 activation in WT and RD mice at $4.5 \mathrm{~h}$ post injection. WT and RD mice treated with or without betaine treatment were injected with saline or LPS/GalN. Hepatic caspase-3 activity was evaluated by measuring the release of 7-amino-4-methylcoumarin (AMC) obtained by the cleavage of the synthetic peptide sequence by caspase- 3 in liver homogenate. Values are means $\pm \operatorname{SEM}(n=8)$. Values not sharing a common letter are statistically different, $p<0.05$.

Apoptotic nuclei were also detected by TUNEL staining. No TUNEL staining was seen in liver slices of WT mice injected with saline or LPS/GalN at 1.5, 3, or $4.5 \mathrm{~h}$ post-injection. Further, no staining was observed in RD mice injected with saline at all time points studied or following LPS/GalN injection at 1.5 or $3 \mathrm{~h}$ post-injection. However, many TUNEL positive hepatocytes were observed in RD mouse liver tissue $4.5 \mathrm{~h}$ post-injection with LPS/GalN. A few positive cells were seen in livers form the mice pretreated with betaine (Figure 6).

(A)

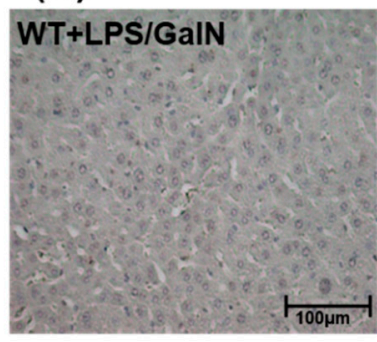

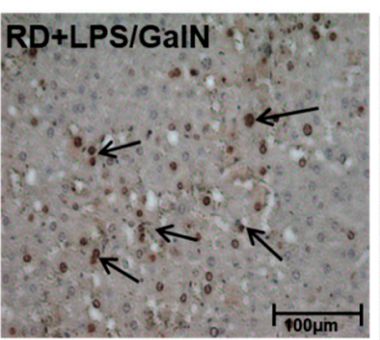

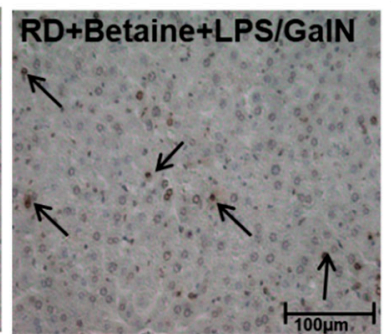

(B)

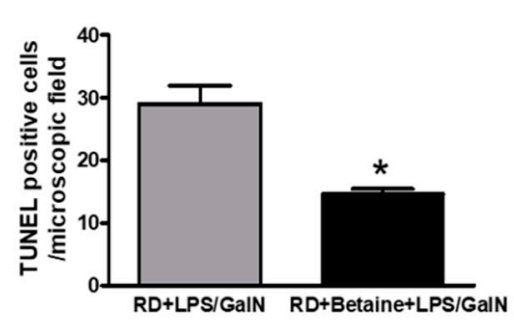

Figure 6. Apoptosis in livers of WT and in RD mice after $4.5 \mathrm{~h}$ post-LPS/GalN injection. Apoptosis was detected by terminal deoxynucleotidyl transferase dUTP nick end-labeling (TUNEL) in liver section. (A) Photographs (200× magnification) show representative liver sections of WT, RD, and betaine-treated RD mice at $4.5 \mathrm{~h}$ of LPS/GalN injection. TUNEL stain (arrows) showed increased liver cell apoptosis in the representative RD mouse after $4.5 \mathrm{~h}$ of LPS/GalN injection, which was significantly reduced in the betaine-pretreated LPS-GalN-injected RDI mouse. (B) Number of TUNEL positive cells/microscopic field. Results are from 10 fields/tissue section, and data pooled from 4 animals/group. Values are mean \pm SEM; ${ }^{*} p<0.05$.

\section{Discussion}

The cascades of events that occur following LPS-GalN administration are well documented. This model of liver injury takes advantage of the ability of the GalN to inhibit transcription and thus to potentiate the toxic effects of LPS to produce typical hepatic cell injury followed by fulminant liver failure within $4-6 \mathrm{~h}$ of LPS/GalN administration [51,52]. In particular, hepatocellular apoptosis has been shown to be an integral part of LPS/GalN- 
induced liver injury [53]. In this study, we utilized LPS/GalN model of liver injury to study the physiological role of ASGP-R. Several features of ASGP-R function prognosticate its therapeutic role in the context of chronic liver diseases. Most important is its role in the phagocytosis of apoptotic bodies [21,22], which by precluding their uptake by the nonparenchymal cells, prevents activation of Kupffer/hepatic stellate cells and liver damage progression [54,55].

In this study, we used a sub-lethal dose of LPS/GalN, which was half of what has been used routinely for inducing fulminant liver failure. While this dose of LPS/GalN induced a TNF- $\alpha$ peak $1.5 \mathrm{~h}$ post injection in WT mice, we observed modest liver injury in this strain of mice by numerous criteria employed in this study. In contrast, the RD mice were susceptible to this sub-lethal dose of LPS/GalN and exhibited considerable liver injury only at $4.5 \mathrm{~h}$ post-injection. This was evidenced by several parameters such as elevated levels of plasma AST and ALT levels (Figure 2), increased liver caspase-3 activity (Figure 5), and considerable cell injury at histological examination by TUNEL-positive test (Figure 6). Further, there appeared to be a temporal sequence of events with TNF- $\alpha$ being the trigger (peak circulating levels of TNF- $\alpha$ was observed $1.5 \mathrm{~h}$ post-injection) to induce apoptosis of GalN-primed hepatocytes and the ensuing liver damage in RD mice. Recognizing that apoptosis is the major player in LPS/GalN-induced liver injury [53] and that ASGP-R plays an important role in removing apoptotic bodies [21,22], these results underscore the physiological importance of ASGP-R in maintaining homeostasis in the liver to prevent the cascade of events that generate liver damage. The dose of LPS/GalN used in this study produced only modest liver injury in WT mice despite a robust peak observed of TNF- $\alpha$ and IL-6 at $1.5 \mathrm{~h}$ post-injection of LPS/GalN. This is because the normally functioning ASGP-R prevented the buildup of apoptotic bodies and thereby also prevented the initiation of the cascade of events to produce fulminant liver failure. However, in RD mice, the absence of functional ASGP-R makes these mice susceptible to the sub-lethal dose of LPS-GalN.

Our laboratory has been studying the protective effects of betaine in a variety of animal and cell-culture models [24-26,28-32]. Betaine can prevent/protect against apoptosis induced by an array of agents [24,46-48]. Strategies increasing the anti-apoptotic armamentarium of hepatocytes have been shown to beneficially impact the outcome of fulminant hepatic failure [56-62]. In this study, we show that betaine is also effective in protecting against LPS-GalN-induced apoptosis in RD mice. While significant attenuation in caspase- 3 activation, AST, and ALT levels were observed in RD mice pretreated with betaine, we observed no change in toxin-induced increases in serum TNF- $\alpha$ level. This indicated that the protective effects of betaine are downstream of TNF- $\alpha$ action. Similar results have also been reported by other investigators who showed the while glycrrhizin or A20 expression protected the livers from LPS/GalN induced liver damage, this occurs in the absence of significant differences in cytokine levels including TNF- $\alpha[56,63]$. While the deleterious effects of TNF- $\alpha$ as a proximal mediator of hepatotoxicity are demonstrated in several models of liver injury including LPS/GalN [8,53], it also a co-mitogen required for proliferation of hepatocytes during liver regeneration, which emphasizes its beneficial effects. Thus, it is possible that maintaining high levels of TNF- $\alpha$ while protecting hepatocytes from apoptosis must be beneficial for liver regeneration and recovery.

To explore the mechanism of betaine action, we looked at the levels of metabolites of the methionine metabolic pathway in the livers of the WT and RD mice with or without betaine treatment and found no difference in the ratios of two important metabolites Sadenosylmethione (SAM) and S-adenosylhomocystiene (SAH), which is reflective of the methylation potential $[25,29,31]$. However, it appeared that the SAM levels were depleted faster in the RD mice as compared to RD mice that were pretreated with betaine (data not shown). SAM is the primary methyl donor in anabolic metabolism, serves as a precursor for glutathione (GSH), and is synthesized by the enzyme methionine adenosyltransferase (MAT) [64]. It has been reported that GalN treatment produces a substantial decrease in cellular SAM levels in hepatocytes by inhibiting MAT activity $[65,66]$. We have previously shown that betaine feeding can dramatically increase SAM levels in livers of rat [25]. 
We believe that betaine pretreatment prevents SAM depletion and thereby prevents the hypomethylation of ribosomal RNA induced by GalN treatment and the "priming" of hepatocytes to subsequent damage $[67,68]$. While many agents have been used to ameliorate LPS/GalN liver damage [56-63,69-72], betaine is inexpensive, bioavailable [73,74], and has no consistent relation with cancer, cardiovascular risk, or risk factors [75], making it a safe therapeutic.

\section{Conclusions}

To summarize, this study underscores the importance of normal ASGP-R function in liver homeostasis. By removing the apoptotic bodies effectively, ASGP-R thereby prevents the cascade of events leading to severe liver injury. Further in the event of impaired ASGP$\mathrm{R}$ function, the administration of betaine can prevent the progression of the severe liver injury by preventing the activation of caspase-3.

Author Contributions: Conceptualization-K.K.K. and C.A.C.; methodology-S.M.L.L. and K.R.; validation-S.M.L.L. and K.R.; investigation-S.M.L.L., C.A.C., B.L.M., N.A.O., K.R., and K.K.K.; resources-K.K.K. and C.A.C.; writing: original draft-K.K.K., S.M.L.L., and K.R.; writing: review and editing-K.K.K. and C.A.C.; project administration, C.A.C. and K.K.K.; funding acquisitionK.K.K. All authors have read and agreed to the published version of the manuscript.

Funding: This work was supported by the National Institutes of Health grant R01 AA026723 (K.K.K.) and Merit Review grant BX004053 (K.K.K.) from the U.S. Department of Veterans Affairs, Biomedical Laboratory Research and Development Service.

Institutional Review Board Statement: The care and use of these mice and the procedures performed on them were approved by the Institutional Animal Care and Use Committee at the Omaha Veterans Affairs Medical Center, Omaha, NE 68105, USA. Protocol code \# 00205.

Conflicts of Interest: The authors declare no conflict of interest. The funders had no role in the design of the study; in the collection, analyses, or interpretation of data; in the writing of the manuscript, or in the decision to publish the results.

\section{References}

1. Grek, A.; Arasi, L. Acute liver failure. AACN Adv. Crit. Care 2016, 27, 420-429. [CrossRef] [PubMed]

2. Squires, J.E.; McKiernan, P.; Squires, R.H. Acute liver failure: An update. Clin. Liver Dis. 2018, 22, 773-805. [CrossRef] [PubMed]

3. Lee, W.M.; Squires, R.H., Jr.; Nyberg, S.L.; Doo, E.; Hoofnagle, J.H. Acute liver failure: Summary of a workshop. Hepatology 2008, 47, 1401-1415. [CrossRef] [PubMed]

4. Lee, W.M.; Stravitz, R.T.; Larson, A.M. Introduction to the revised american association for the study of liver diseases position paper on acute liver failure 2011. Hepatology 2012, 55, 965-967. [CrossRef] [PubMed]

5. Cho, H.I.; Hong, J.M.; Choi, J.W.; Choi, H.S.; Kwak, J.H.; Lee, D.U.; Lee, S.K.; Lee, S.M. Beta-caryophyllene alleviates dgalactosamine and lipopolysaccharide-induced hepatic injury through suppression of the tlr4 and rage signaling pathways. Eur. J. Pharmacol. 2015, 764, 613-621. [CrossRef] [PubMed]

6. Shi, T.; Song, W.; Xu, R. Autophagy and er stress in lps/galninduced acute liver injury. Mol. Med. Rep. 2017, 16, 7001-7005. [CrossRef]

7. Galanos, C.; Freudenberg, M.A.; Reutter, W. Galactosamine-induced sensitization to the lethal effects of endotoxin. Proc. Natl. Acad. Sci. USA 1979, 76, 5939-5943. [CrossRef]

8. Leist, M.; Gantner, F.; Bohlinger, I.; Tiegs, G.; Germann, P.G.; Wendel, A. Tumor necrosis factor-induced hepatocyte apoptosis precedes liver failure in experimental murine shock models. Am. J. Pathol. 1995, 146, 1220-1234.

9. Li, X.; Gou, C.; Yang, H.; Qiu, J.; Gu, T.; Wen, T. Echinacoside ameliorates d-galactosamine plus lipopolysaccharide-induced acute liver injury in mice via inhibition of apoptosis and inflammation. Scand. J. Gastroenterol. 2014, 49, 993-1000. [CrossRef]

10. Zhang, Z.; Tian, L.; Jiang, K. Propofol attenuates inflammatory response and apoptosis to protect d-galactosamine/lipopolysaccharide induced acute liver injury via regulating tlr4/nf-kappab/nlrp3 pathway. Int. Immunopharmacol. 2019, 77, 105974. [CrossRef]

11. Kmiec, Z.; Smolenski, R.T.; Zych, M.; Mysliwski, A. The effects of galactosamine on utp levels in the livers of young, adult and old rats. Acta Biochim. Pol. 2000, 47, 349-353. [CrossRef] [PubMed]

12. Grun, B.R.; Berger, U.; Oberdorfer, F.; Hull, W.E.; Ostertag, H.; Keppler, D. In vivo metabolism and utp-depleting action of 2-deoxy-2-fluoro-d-galactose. Adv. Enzym. Regul. 1990, 30, 231-242. [CrossRef]

13. Zhang, S.; Yang, N.; Ni, S.; Li, W.; Xu, L.; Dong, P.; Lu, M. Pretreatment of lipopolysaccharide (lps) ameliorates d-galn/lps induced acute liver failure through tlr4 signaling pathway. Int. J. Clin. Exp. Pathol. 2014, 7, 6626-6634.

14. Su, G.L. Lipopolysaccharides in liver injury: Molecular mechanisms of kupffer cell activation. Am. J. Physiol. Gastrointest. Liver Physiol. 2002, 283, G256-G265. [CrossRef] [PubMed] 
15. Yee, S.B.; Ganey, P.E.; Roth, R.A. The role of kupffer cells and tnf-alpha in monocrotaline and bacterial lipopolysaccharide-induced liver injury. Toxicol. Sci. 2003, 71, 124-132. [CrossRef] [PubMed]

16. Dorman, R.B.; Gujral, J.S.; Bajt, M.L.; Farhood, A.; Jaeschke, H. Generation and functional significance of cxc chemokines for neutrophil-induced liver injury during endotoxemia. Am. J. Physiol. Gastrointest. Liver Physiol. 2005, 288, G880-G886. [CrossRef] [PubMed]

17. Bantel, H.; Schulze-Osthoff, K. Mechanisms of cell death in acute liver failure. Front. Physiol. 2012, 3, 79. [CrossRef]

18. Li, Z.; Weinman, S.A. Regulation of hepatic inflammation via macrophage cell death. Semin. Liver Dis. 2018, 38, 340-350. [CrossRef]

19. Maes, M.; Vinken, M.; Jaeschke, H. Experimental models of hepatotoxicity related to acute liver failure. Toxicol. Appl. Pharmacol. 2016, 290, 86-97. [CrossRef]

20. Gujral, J.S.; Hinson, J.A.; Farhood, A.; Jaeschke, H. Nadph oxidase-derived oxidant stress is critical for neutrophil cytotoxicity during endotoxemia. Am. J. Physiol. Gastrointest. Liver Physiol. 2004, 287, G243-G252. [CrossRef]

21. Dini, L.; Autuori, F.; Lentini, A.; Oliverio, S.; Piacentini, M. The clearance of apoptotic cells in the liver is mediated by the asialoglycoprotein receptor. FEBS Lett. 1992, 296, 174-178. [CrossRef]

22. McVicker, B.L.; Tuma, D.J.; Kubik, J.A.; Hindemith, A.M.; Baldwin, C.R.; Casey, C.A. The effect of ethanol on asialoglycoprotein receptor-mediated phagocytosis of apoptotic cells by rat hepatocytes. Hepatology 2002, 36, 1478-1487. [PubMed]

23. Ji, C.; Kaplowitz, N. Betaine decreases hyperhomocysteinemia, endoplasmic reticulum stress, and liver injury in alcohol-fed mice. Gastroenterology 2003, 124, 1488-1499. [CrossRef]

24. Kharbanda, K.K.; Rogers, D.D., 2nd; Mailliard, M.E.; Siford, G.L.; Barak, A.J.; Beckenhauer, H.C.; Sorrell, M.F.; Tuma, D.J. Role of elevated s-adenosylhomocysteine in rat hepatocyte apoptosis: Protection by betaine. Biochem. Pharmacol. 2005, 70, $1883-1890$. [CrossRef] [PubMed]

25. Kharbanda, K.K.; Mailliard, M.E.; Baldwin, C.R.; Beckenhauer, H.C.; Sorrell, M.F.; Tuma, D.J. Betaine attenuates alcoholic steatosis by restoring phosphatidylcholine generation via the phosphatidylethanolamine methyltransferase pathway. J. Hepatol. 2007, 46, 314-321. [CrossRef] [PubMed]

26. Kharbanda, K.K.; Mailliard, M.E.; Baldwin, C.R.; Sorrell, M.F.; Tuma, D.J. Accumulation of proteins bearing atypical isoaspartyl residues in livers of alcohol-fed rats is prevented by betaine administration: Effects on protein-l-isoaspartyl methyltransferase activity. J. Hepatol. 2007, 46, 1119-1125. [CrossRef] [PubMed]

27. Purohit, V.; Abdelmalek, M.F.; Barve, S.; Benevenga, N.J.; Halsted, C.H.; Kaplowitz, N.; Kharbanda, K.K.; Liu, Q.Y.; Lu, S.C.; McClain, C.J.; et al. Role of s-adenosylmethionine, folate, and betaine in the treatment of alcoholic liver disease: Summary of a symposium. Am. J. Clin. Nutr. 2007, 86, 14-24. [CrossRef]

28. Kharbanda, K.K.; Todero, S.L.; Ward, B.W.; Cannella, J.J., 3rd; Tuma, D.J. Betaine administration corrects ethanol-induced defective vldl secretion. Mol. Cell. Biochem. 2009, 327, 75-78. [CrossRef]

29. Kharbanda, K.K. Alcoholic liver disease and methionine metabolism. Semin. Liver Dis. 2009, 29, 155-165. [CrossRef]

30. Kharbanda, K.K.; Todero, S.L.; King, A.L.; Osna, N.A.; McVicker, B.L.; Tuma, D.J.; Wisecarver, J.L.; Bailey, S.M. Betaine treatment attenuates chronic ethanol-induced hepatic steatosis and alterations to the mitochondrial respiratory chain proteome. Int. J. Hepatol. 2012, 2012, 962183. [CrossRef]

31. Kharbanda, K.K. Methionine metabolic pathway in alcoholic liver injury. Curr. Opin. Clin. Nutr. Metab. Care 2013, 16, 89-95. [CrossRef] [PubMed]

32. Kharbanda, K.K.; Ronis, M.J.J.; Shearn, C.T.; Petersen, D.R.; Zakhari, S.; Warner, D.R.; Feldstein, A.E.; McClain, C.J.; Kirpich, I.A. Role of nutrition in alcoholic liver disease: Summary of the symposium at the esbra 2017 congress. Biomolecules $2018,8,16$. [CrossRef] [PubMed]

33. Varatharajalu, R.; Garige, M.; Leckey, L.C.; Gong, M.; Lakshman, M.R. Betaine protects chronic alcohol and omega-3 pufamediated down-regulations of pon1 gene, serum pon1 and homocysteine thiolactonase activities with restoration of liver gsh. Alcohol. Clin. Exp. Res. 2010, 34, 424-431. [CrossRef] [PubMed]

34. Varatharajalu, R.; Garige, M.; Leckey, L.C.; Arellanes-Robledo, J.; Reyes-Gordillo, K.; Shah, R.; Lakshman, M.R. Adverse signaling of scavenger receptor class b1 and pgc1s in alcoholic hepatosteatosis and steatohepatitis and protection by betaine in rat. Am. J. Pathol. 2014, 184, 2035-2044. [CrossRef] [PubMed]

35. Junnila, M.; Barak, A.J.; Beckenhauer, H.C.; Rahko, T. Betaine reduces hepatic lipidosis induced by carbon tetrachloride in sprague-dawley rats. Vet. Hum. Toxicol. 1998, 40, 263-266. [PubMed]

36. Junnila, M.; Rahko, T.; Sukura, A.; Lindberg, L.A. Reduction of carbon tetrachloride-induced hepatotoxic effects by oral administration of betaine in male han-wistar rats: A morphometric histological study. Vet. Pathol. 2000, 37, 231-238. [CrossRef]

37. Murakami, T.; Nagamura, Y.; Hirano, K. The recovering effect of betaine on carbon tetrachloride-induced liver injury. J. Nutr. Sci. Vitaminol. 1998, 44, 249-255. [CrossRef]

38. Tsai, M.T.; Chen, C.Y.; Pan, Y.H.; Wang, S.H.; Mersmann, H.J.; Ding, S.T. Alleviation of carbon-tetrachloride-induced liver injury and fibrosis by betaine supplementation in chickens. Evid. Based Complement. Altern. Med. 2015, 2015, 725379. [CrossRef]

39. Abdelmalek, M.F.; Angulo, P.; Jorgensen, R.A.; Sylvestre, P.B.; Lindor, K.D. Betaine, a promising new agent for patients with nonalcoholic steatohepatitis: Results of a pilot study. Am. J. Gastroenterol. 2001, 96, 2711-2717. [CrossRef] 
40. Kathirvel, E.; Morgan, K.; Nandgiri, G.; Sandoval, B.C.; Caudill, M.A.; Bottiglieri, T.; French, S.W.; Morgan, T.R. Betaine improves nonalcoholic fatty liver and associated hepatic insulin resistance: A potential mechanism for hepatoprotection by betaine. Am. J. Physiol. Gastrointest. Liver Physiol. 2010, 299, G1068-G1077. [CrossRef]

41. Mukherjee, S.; Bernard, T.; Kharbanda, K.; Barak, A.J.; Sorrell, M.F.; Tuma, D.J. Impact of betaine on hepatic fibrosis and homocysteine in non-alcoholic steatohepatitis-a prospective cohort study. Open Transl. J. 2011, 3, 1-4.

42. Song, Z.; Deaciuc, I.; Zhou, Z.; Song, M.; Chen, T.; Hill, D.; McClain, C.J. Involvement of amp-activated protein kinase in beneficial effects of betaine on high-sucrose diet-induced hepatic steatosis. Am. J. Physiol. Gastrointest. Liver Physiol. 2007, 293, G894-G902. [CrossRef] [PubMed]

43. Wang, Z.; Yao, T.; Pini, M.; Zhou, Z.; Fantuzzi, G.; Song, Z. Betaine improved adipose tissue function in mice fed a high-fat diet: A mechanism for hepatoprotective effect of betaine in nonalcoholic fatty liver disease. Am. J. Physiol. Gastrointest. Liver Physiol. 2010, 298, G634-G642. [CrossRef] [PubMed]

44. Zhang, W.; Wang, L.W.; Wang, L.K.; Li, X.; Zhang, H.; Luo, L.P.; Song, J.C.; Gong, Z.J. Betaine protects against high-fat-dietinduced liver injury by inhibition of high-mobility group box 1 and toll-like receptor 4 expression in rats. Dig. Dis. Sci. 2013, 58, 3198-3206. [CrossRef]

45. Kawakami, S.; Han, K.H.; Nakamura, Y.; Shimada, K.; Kitano, T.; Aritsuka, T.; Nagura, T.; Ohba, K.; Nakamura, K.; Fukushima, M. Effects of dietary supplementation with betaine on a nonalcoholic steatohepatitis (nash) mouse model. J. Nutr. Sci. Vitaminol. 2012, 58, 371-375. [CrossRef]

46. Ji, C.; Deng, Q.; Kaplowitz, N. Role of tnf-alpha in ethanol-induced hyperhomocysteinemia and murine alcoholic liver injury. Hepatology 2004, 40, 442-451. [CrossRef]

47. Horio, M.; Ito, A.; Matsuoka, Y.; Moriyama, T.; Orita, Y.; Takenaka, M.; Imai, E. Apoptosis induced by hypertonicity in madin darley canine kidney cells: Protective effect of betaine. Nephrol. Dial. Transplant. 2001, 16, 483-490. [CrossRef]

48. Im, A.R.; Kim, Y.H.; Uddin, M.R.; Chae, S.; Lee, H.W.; Kim, Y.S.; Lee, M.Y. Betaine protects against rotenone-induced neurotoxicity in pc12 cells. Cell. Mol. Neurobiol. 2013, 33, 625-635. [CrossRef]

49. Dalton, S.R.; Lee, S.M.; King, R.N.; Nanji, A.A.; Kharbanda, K.K.; Casey, C.A.; McVicker, B.L. Carbon tetrachloride-induced liver damage in asialoglycoprotein receptor-deficient mice. Biochem. Pharmacol. 2009, 77, 1283-1290. [CrossRef]

50. Dalton, S.R.; Wiegert, R.L.; Baldwin, C.R.; Kassel, K.M.; Casey, C.A. Impaired receptor-mediated endocytosis by the asialoglycoprotein receptor in ethanol-fed mice: Implications for studying the role of this receptor in alcoholic apoptosis. Biochem. Pharmacol. 2003, 65, 535-543. [CrossRef]

51. Okumura, A.; Saito, T.; Tobiume, M.; Hashimoto, Y.; Sato, Y.; Umeyama, T.; Nagi, M.; Tanabe, K.; Unoki-Kubota, H.; Kaburagi, Y.; et al. Alleviation of lipopolysaccharide/d-galactosamine-induced liver injury in leukocyte cell-derived chemotaxin 2 deficient mice. Biochem. Biophys. Rep. 2017, 12, 166-171. [CrossRef]

52. Hishinuma, I.; Nagakawa, J.; Hirota, K.; Miyamoto, K.; Tsukidate, K.; Yamanaka, T.; Katayama, K.; Yamatsu, I. Involvement of tumor necrosis factor-alpha in development of hepatic injury in galactosamine-sensitized mice. Hepatology 1990, 12, $1187-1191$. [CrossRef]

53. Wu, Y.H.; Hu, S.Q.; Liu, J.; Cao, H.C.; Xu, W.; Li, Y.J.; Li, L.J. Nature and mechanisms of hepatocyte apoptosis induced by d-galactosamine/lipopolysaccharide challenge in mice. Int. J. Mol. Med. 2014, 33, 1498-1506. [CrossRef]

54. Canbay, A.; Taimr, P.; Torok, N.; Higuchi, H.; Friedman, S.; Gores, G.J. Apoptotic body engulfment by a human stellate cell line is profibrogenic. Lab. Investig. 2003, 83, 655-663. [CrossRef]

55. Ganesan, M.; New-Aaron, M.; Dagur, R.S.; Makarov, E.; Wang, W.; Kharbanda, K.K.; Kidambi, S.; Poluektova, L.Y.; Osna, N.A. Alcohol metabolism potentiates HIV-induced hepatotoxicity: Contribution to end-stage liver disease. Biomolecules $2019,9,851$. [CrossRef]

56. Arvelo, M.B.; Cooper, J.T.; Longo, C.; Daniel, S.; Grey, S.T.; Mahiou, J.; Czismadia, E.; Abu-Jawdeh, G.; Ferran, C. A20 protects mice from d-galactosamine/lipopolysaccharide acute toxic lethal hepatitis. Hepatology 2002, 35, 535-543. [CrossRef]

57. Rousta, A.M.; Mirahmadi, S.M.; Shahmohammadi, A.; Ramzi, S.; Baluchnejadmojarad, T.; Roghani, M. S-allyl cysteine, an active ingredient of garlic, attenuates acute liver dysfunction induced by lipopolysaccharide/ d-galactosamine in mouse: Underlying mechanisms. J. Biochem. Mol. Toxicol. 2020, 26, e22518. [CrossRef]

58. Luo, Y.; Yang, Y.; Shen, Y.; Li, L.; Huang, J.; Tang, L.; Zhang, L. Luzindole attenuates lps/d-galactosamine-induced acute hepatitis in mice. Innate Immune 2020, 26, 319-327. [CrossRef]

59. Peng, X.; Yang, Y.; Tang, L.; Wan, J.; Dai, J.; Li, L.; Huang, J.; Shen, Y.; Lin, L.; Gong, X.; et al. Therapeutic benefits of apocynin in mice with lipopolysaccharide/d-galactosamine-induced acute liver injury via suppression of the late stage pro-apoptotic ampk/jnk pathway. Biomed. Pharmacother. 2020, 125, 110020. [CrossRef]

60. Lv, H.; An, B.; Yu, Q.; Cao, Y.; Liu, Y.; Li, S. The hepatoprotective effect of myricetin against lipopolysaccharide and dgalactosamine-induced fulminant hepatitis. Int. J. Biol. Macromol. 2020, 155, 1092-1104. [CrossRef]

61. Gao, K.; Liu, F.; Chen, X.; Chen, M.; Deng, Q.; Zou, X.; Guo, H. Crocetin protects against fulminant hepatic failure induced by lipopolysaccharide/d-galactosamine by decreasing apoptosis, inflammation and oxidative stress in a rat model. Exp. Ther. Med. 2019, 18, 3775-3782. [CrossRef]

62. Yang, C.; He, L.; Wang, C.; Huang, Y.; Wang, A.; Li, X.; Ao, J. Dexmedetomidine alleviated lipopolysaccharide/d-galactosamineinduced acute liver injury in mice. Int. Immunopharmacol. 2019, 72, 367-373. [CrossRef] 
63. Yoshida, T.; Abe, K.; Ikeda, T.; Matsushita, T.; Wake, K.; Sato, T.; Sato, T.; Inoue, H. Inhibitory effect of glycyrrhizin on lipopolysaccharide and d-galactosamine-induced mouse liver injury. Eur. J. Pharmacol. 2007, 576, 136-142. [CrossRef]

64. Mato, J.M.; Alvarez, L.; Ortiz, P.; Pajares, M.A. S-adenosylmethionine synthesis: Molecular mechanisms and clinical implications. Pharmacol. Ther. 1997, 73, 265-280. [CrossRef]

65. Ozturk, M.; Lemonnier, F.; Cresteil, D.; Lemonnier, A. Changes in methionine metabolism induced by d-galactosamine in isolated rat hepatocytes. Biochem. Pharmacol. 1986, 35, 4223-4228. [CrossRef]

66. Lu, S.C.; Mato, J.M. S-adenosylmethionine in liver health, injury, and cancer. Physiol. Rev. 2012, 92, 1515-1542. [CrossRef]

67. Clawson, G.A.; Sesno, J.; Milam, K.; Wang, Y.F.; Gabriel, C. The hepatocyte protein synthesis defect induced by galactosamine involves hypomethylation of ribosomal rna. Hepatology 1990, 11, 428-434. [CrossRef]

68. Halsted, C.H.; Medici, V. Aberrant hepatic methionine metabolism and gene methylation in the pathogenesis and treatment of alcoholic steatohepatitis. Int. J. Hepatol. 2012, 2012, 959746. [CrossRef]

69. Li, Z.; Feng, H.; Han, L.; Ding, L.; Shen, B.; Tian, Y.; Zhao, L.; Jin, M.; Wang, Q.; Qin, H.; et al. Chicoric acid ameliorate inflammation and oxidative stress in lipopolysaccharide and d-galactosamine induced acute liver injury. J. Cell. Mol. Med. 2020, 24, 3022-3033. [CrossRef]

70. Zhou, R.J.; Zhao, Y.; Fan, K.; Xie, M.L. Protective effect of apigenin on d-galactosamine/lps-induced hepatocellular injury by increment of nrf-2 nucleus translocation. Naunyn-Schmiedeberg's Arch. Pharmacol. 2020, 393, 929-936. [CrossRef]

71. Lyu, Z.; Ji, X.; Chen, G.; An, B. Atractylodin ameliorates lipopolysaccharide and d-galactosamine-induced acute liver failure via the suppression of inflammation and oxidative stress. Int. Immunopharmacol. 2019, 72, 348-357. [CrossRef]

72. Liu, T.G.; Sha, K.H.; Zhang, L.G.; Liu, X.X.; Yang, F.; Cheng, J.Y. Protective effects of alpinetin on lipopolysaccharide/dgalactosamine-induced liver injury through inhibiting inflammatory and oxidative responses. Microb. Pathog. 2019, 126, $239-244$. [CrossRef]

73. Thomes, P.G.; Osna, N.A.; Bligh, S.M.; Tuma, D.J.; Kharbanda, K.K. Role of defective methylation reactions in ethanol-induced dysregulation of intestinal barrier integrity. Biochem. Pharmacol. 2015, 96, 30-38. [CrossRef]

74. Thomes, P.G.; Bligh, S.M.; Kharbanda, K.K. Multiple roles of betaine against alcohol-induced liver injury. In Betaine, Chemistry, Analysis, Function and Effects; Preedy, V.R., Ed.; Royal Society of Chemistry: London, UK, 2015; pp. 285-310.

75. Ueland, P.M. Choline and betaine in health and disease. J. Inherit. Metab. Dis. 2011, 34, 3-15. [CrossRef] 